\title{
Recurrent Squamous Cell Carcinoma
}

National Cancer Institute

\section{Source}

National Cancer Institute. Recurrent Squamous Cell Carcinoma. NCI Thesaurus. Code C162652.

A squamous cell carcinoma that has recurred after a period of remission. 